International Research Journal of Management, IT \& Social Sciences
Available online at https://sloap.org/journals/index.php/irjmis/
Vol. 6 No. 2, March 2019, pages: 63 71
ISSN: 2395-7492
https://doi.org/10.21744/irjmis.v6n2.611

\title{
The Relationship between Organizational Justice with Job Satisfaction and Organizational Citizenship Behavior
}

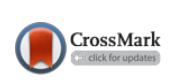

Nurul Indahyati ${ }^{a}$

Desak Ketut Sintaasih ${ }^{b}$

\section{Article history:}

Received: 9 September 2018

Accepted: 31 January 2019

Published: 31 March 2019

\section{Keywords:}

behavior;

citizenship;

job satisfaction;

organizational justice;

organizational;

\begin{abstract}
This study aims to explain the effect of organizational justice on job satisfaction and organizational citizenship behavior. The technique used to test the research hypothesis used Structural Equation Modeling (SEM) analysis techniques using SMARTPLS assistance, using IBM SPSS Statistics 22, and 65 respondents in this study, taken using Purposive Sampling techniques. The results of the study show that (1) distribution justice has a positive and significant effect on job satisfaction. (2) procedural justice has a positive and not significant effect on job satisfaction. (3) interactional justice has a positive and not significant effect on job satisfaction. (4) justice distribution has a positive and insignificant effect on organizational citizenship behavior. (5) procedural justice has a positive and insignificant effect on organizational citizenship behavior. (6) interactional justice has a positive and insignificant effect on organizational citizenship behavior. (7) job satisfaction has a positive and significant effect on organizational citizenship behavior.
\end{abstract}

2395-7492@ Copyright 2019. The Author. This is an open-access article under the CC BY-SA license (https://creativecommons.org/licenses/by-sa/4.0/) All rights reserved.

\section{Author correspondence:}

Nurul Indahyati,

Faculty Economic and Business of Udayana University, Bali, Indonesia.

Email address: nurul.indahyati@bpjsketenagakerjaan.go.id

\section{Introduction}

George \& Bettenhausen (1990), prove the relationship of organizational effectiveness with OCB with the argument that OCB can improve company performance by providing a positive impact on the social situation of the organization, minimizing friction, and increasing company efficiency. Podsakoff \& Mackenzie (1997), revealed that when an employee helps his coworkers, it can increase employee productivity.

In order for an employee to do OCB to the fullest, it can be influenced by several conditions. Research by Jehad et al., (2011), correlate job satisfaction with OCB and it was found that job satisfaction was positively and significantly correlated with OCB, especially in the dimensions of conscientiousness, sportsmanship, and civic virtue, but positively and not significantly correlated with the dimensions of courtesy and altruism. This shows that when employees are

\footnotetext{
a Faculty Economic and Business of Udayana University, Bali, Indonesia

${ }^{\mathrm{b}}$ Faculty Economic and Business of Udayana University, Bali, Indonesia
} 
satisfied because the company is attentive and cares about personal growth, development, and progress in their work, employees will reciprocate by showing positive attitudes and behaviors that will benefit their organization in general rather than to certain individuals in the organization.

On the other hand, Rad and Yarmohammadian in Al-zu'bi (2010), mention that an organization cannot succeed without the hard work and commitment of its employees. Job satisfaction and employee work performance are the main keys that affect company performance. One of the factors that influence job satisfaction is organizational justice, which is defined as individual perceptions and reaction attitudes towards the perceived justice of the treatment of the organization (Al-zu'bi, 2010).

So it can be concluded based on the above research, that organizational justice plays an important role in job satisfaction that can lead to OCB for employees.

Gul \& Ince (2011), state that the main administrative instruments in organizations to foster employee loyalty are management systems based on justice. Oreg \& Dam (2008), examined the relationship between organizational justice and organizational change. To be able to withstand very rapid environmental changes, an organization needs to develop major changes such as mergers, layoffs, product innovation, the application of new technology systems. These changes occur, have a profound effect on each individual in the organization, and result in strong reactions that can hinder the process of change which ultimately affects the outcome of the company and also employees. Under these conditions, perceptions of justice play a very important role. Employees' perceptions of the justice of the changes made, may affect their cooperation with the changes themselves and their assessment of the parties responsible for the change decisions.

Colquitt et al., (2001), divide organizational justice into 3, namely distribution, procedural and interactional justice (which consists of interpersonal and informational). Cropanzo and Greenberg in Gul (2011), define organizational justice as perception and evaluation of compliance with organizational practices and related to processes and outcomes. Another definition expressed by Folger and Cropanzano in Van Dam (2008), which states that organizational justice is a condition of employees that makes individuals inside believe it has been treated fairly or unfairly.

Some studies say, that the theory of organizational justice arises based on Adams' equity theory (Gul \& Ince, 2011), according to this theory that an individual in an organization tends to always compare the efforts and benefits they get with other individuals. If employees feel treated fairly by the company, then they will give a reward to the company by doing Organizational Citizenship Behavior (Erkutlu, 2010).

Altinkurt \& Yilmaz (2012), conducted a study of the relationship between organizational justice, organizational trust and Organizational Citizenship Behaviors in Turkey. The results of this study indicate that organizational justice has a positive effect on Organizational Citizenship Behavior. In line with this study, the same results were also found in Gul and Ince's (2011), Erkutlu (2010) study, which added variable organizational culture as a moderating role in the relationship between organizational justice and OCB.

In some literature, organizational justice is a determining factor for several company outcomes, including job satisfaction, organizational commitment, trust, authority evaluation, Organizational Citizenship Behavior (OCBs), withdrawal, Negative Reaction and performance (Colquitt et al., 2001). The positive relationship between organizational justice and job satisfaction is found in research, among others (Colquitt et al., 2001; Al-Zu'bi, 2010; Finch \& Campbell, 2004).

\section{Literature Review}

Some studies divide organizational justice into 3 dimensions, namely distribution, procedural, and interactional justice (Aslam et al., 2006; Bakhsi \& Kumar, 2009; Al-Zu'bi, 2010; Al-tahayneh, 2014). In Al-tahayneh's (2014) study conducted on physical education teachers in Jordan, justice distribution was ranked third (after interactional justice and procedural justice) as predictors of job satisfaction. Another study that shows distribution justice as a predictor of weak job satisfaction is Kwaitt et al., (2010). Based on these two studies, distribution justice was found to be positively correlated with job satisfaction, but not always a good predictor of job satisfaction. Different results were found in the study of Bakhsi and Kumar (2009) conducted on employees at the University of medicine and research conducted by McFarlin \& Sweeney (1992), found fair distribution was the best predictor of job satisfaction.

H1: Justice distribution has a positive and significant effect on job satisfaction

According to Brockner \& Weisenfeld (1996), procedural justice will be felt more important when the outcome/outcome is felt to be unprofitable. Many studies have shown that procedural justice is a good predictor of job satisfaction, such as Sareshkeh et al., (2012), find procedural justice directly influences satisfaction with coworkers and supervisors, Lotfi \& Pour (2012), find only procedural justice can be a predictor of job satisfaction, Kwaitt et al., (2010), found that procedural justice is a better predictor of job satisfaction rather than distribution justice, but Bakhsi \& Kumar (2009), found that procedural justice has no relationship with job satisfaction. 
H2: Procedural justice has a positive and significant effect on job satisfaction

Interactional Justice is concerned with the quality of relations between superiors and subordinates. Al-tahayneh (2014) and Halim et al., (2011), who conducted research on teachers showed that interactional justice is the best predictor of job satisfaction. Sareshkeh et al., (2012), proved that interactional justice directly affects satisfaction with colleagues and supervisors, while Lotfi \& Pour (2012), did not find a relationship between interactional justice and job satisfaction.

H3: Interactional Justice has a positive and significant effect on job satisfaction

Jafari \& Bidarian (2012), conducted research at the Islamic Azad University in Iran found a weak relationship between fair distribution and OCB, and no differences were found between men and women. The results of other studies indicate a strong and positive relationship between distribution justice and OCB, namely: Gilaninia \& Abdesonboli (2011); Chegini (2009); while Arjmand \& Asgari (2011), found no significant relationship between equity distribution and OCB.

H4: Distribution Justice has a positive and significant effect on Organizational Citizenship Behavior

Procedural justice is about an individual's perception of the fair/not procedure/method used for a decision made. Arjmand \& Asgari (2011), found a significant relationship between procedural justice and OCB, the higher the justice perceived by an employee, the higher the OCB level of the employee.

H5: Procedural Justice has a positive and significant effect on Organizational Citizenship Behavior

The interactional justice dimension is the relationship between employees and their superiors. Jafari \& Bidarian (2012) and Arjmand \& Asgari (2011), studies in Iranian universities prove that interactional justice does not have a significant relationship with OCB, this is because OCB employees are more influenced by social and cultural factors and religious norms in Iran rather than boss and subordinate relations. Different results were found in Gyninia \& Abdesonboli (2011), studies which conducted research at Rasht Government Hospital, which showed that interactional justice had a significant relationship with OCB.

H6: Interactional Justice has a positive and significant effect on Organizational Citizenship Behavior

The meta-analysis conducted by Organ \& Ryan (1995) in 28 studies found a correlation between job satisfaction and OCB, then re-examined in 1997 by an organ that connected moral and OCB. The moral is measured from 4 dimensions, namely job satisfaction, justice, commitment, and leadership. While OCB is measured from two dimensions, namely helping and compliance dimensions. The study found that employee morale had an effect on OCB, where the dimensions of job satisfaction were the most influential dimensions of morality, followed by justice. Job satisfaction is the best single indicator for OCB (Organ et al., 2006).

H7: Job satisfaction has a positive and significant effect on Organizational Citizenship Behavior.

\section{Materials and Methods}

The population in this study were 65 employees working at PT XYZ in Bali. In 2017 there were 65 permanent employees in the Bali region due to the small population, so in this study saturated sampling techniques were carried out, ie all population numbers were used as samples. The instrument used in this study was a questionnaire with a Likert scale. The data analysis technique uses Structural Equation Modeling (SEM) analysis techniques using SMARTPLS assistance.

\section{Results and Discussions}

Goodness of fit structural models on the inner model are tested using values predictive - relevance (Q2). R2 value of each endogenous variable in this study can be seen in Table 1.

Table 1

$\mathrm{R}^{2}$ Value

\begin{tabular}{lr}
\hline \multicolumn{1}{c}{ Endogenous } & $R$-Square \\
\hline Job Satisfaction & 0,976 \\
Organizational Citizenship Behavior $(O C B)$ & 0,985 \\
\hline
\end{tabular}

Primary Data, 2018

Indahyati, N., \& Sintaasih, D. K. (2019). The relationship between organizational justice with job satisfaction and organizational citizenship behavior. International Research Journal of Management, IT and Social Sciences, 6(2), 63-71. https://doi.org/10.21744/irjmis.v6n2.611 
Predictive value - relevance is obtained by the formula:

$\mathrm{Q}^{2}=1-\left(1-\mathrm{R} 1^{2}\right)\left(1-\mathrm{R} 2^{2}\right)$

$\mathrm{Q}^{2}=1-(1-0.976)(1-0.985)$

$\mathrm{Q}^{2}=1-(0.025)(0.015)$

$\mathrm{Q}^{2}=0.9996$

The above results indicate predictive - relevance value of 0.9996 , this value is $>0$. So that it can be interpreted that $99.96 \%$ of the variation in the variable is explained by the variables used in the model. The remaining $0.04 \%$ is explained by other factors outside the model. With this result, it can be concluded that this model has relevant predictive values.

Table 2

Partial least square testing result

\begin{tabular}{lcccc}
\hline & $\begin{array}{c}\text { Original } \\
\text { Sample }(\mathrm{O})\end{array}$ & $\begin{array}{c}\text { T Statistics } \\
(|\mathrm{O} / \mathrm{STDEV}|)\end{array}$ & $\begin{array}{c}\mathrm{P} \\
\text { Values }\end{array}$ & Description \\
\hline Dist. Justice -> Satisfaction & 0.445 & 2.037 & 0.042 & Sig. \\
Dist. Justice -> OCB & 0.161 & 0.896 & 0.731 & Not. Sig \\
Inter. Justice -> Satisfaction & 0.162 & 0.709 & 0.479 & Not. Sig \\
Inter. Justice -> OCB & 0.074 & 0.325 & 0.746 & Not. Sig \\
Proc. Justice -> Satisfaction & 0.383 & 1.672 & 0.095 & Not. Sig \\
Proc. Justice -> OCB & 0.056 & 0.317 & 0.751 & Not. Sig \\
Satisfaction -> OCB & 0.705 & 6.17 & 0 & Sig. \\
\hline
\end{tabular}

Primary Data, 2018

\section{The Effect of distributive justice on job satisfaction}

The results of data analysis statistically show that fair distribution has a positive and significant effect on job satisfaction, this means that salary levels, work schedules, job loading and overall reciprocity of the company play a significant role in employee job satisfaction. The largest outer loading value in the distribution justice variable is a fair workload indicator with a value of 0.840 . This shows that the indicator reflects the construct of Justice Distribution. In line with the results of this study, Bakhsi \& Kumar's (2009), the study of employees at the University of Medicine and research conducted by McFarlin \& Sweeney (1992), found distribution justice to be the best predictor of job satisfaction.

\section{The Effect of procedural justice on job satisfaction}

The results of statistical data analysis showed that procedural justice had a positive and not significant effect on job satisfaction. The biggest outer loading value in procedural justice variables is the indicator "to make my boss's decision to collect accurate and complete information" with a value of 0.881 . This figure shows that the indicator reflects the construct of procedural justice. Positive and insignificant relationships show more accurate information, so it does not affect the level of job satisfaction. This is due, things that relate to work decisions have operational standard procedures that apply throughout Indonesia. The results of this study are in accordance with the results of previous studies in which Bakhsi \& Kumar (2009), found that procedural justice did not have a relationship with job satisfaction.

The effect of interactional justice on job satisfaction.

The results of statistical data analysis show that interactional justice has a positive and not significant effect on job satisfaction. The largest outer loading value in interactional justice variables is an indicator when a decision is made related to work by showing the rights as employees with a value of 0.885 . This means that when a decision is made related to work by showing the rights as employees, it does not affect the level of job satisfaction. The existence of SOPs and regulations that apply in BPJS Employment, causing interactional justice does not have a significant effect on job satisfaction. The results of this study are consistent with the results of previous studies in which Lotfi \& Pour (2012), did not find an association between interactional justice and job satisfaction.

\section{The Effect of distributive justice on organizational citizenship behavior (OCB)}

The results of statistical data analysis showed that fair distribution had a positive and insignificant effect on organizational citizenship behavior (OCB). The largest outer loading value in the distribution justice variable is a fair 
workload indicator with a value of 0.840 . This means that the fairer the workload is given, it does not affect organizational citizenship behavior (OCB). The fact that happened in the field, OCB has become a daily part of BPJS Employment employees. The high number of participation makes employees automatically implement OCB. The results of this study are consistent with the results of a previous study in which Jafari \& Bidarian (2012) conducted research at the Islamic Azad University in Iran found a weak relationship between fair distribution and OCB, and no differences were found between men and women. The results of other studies indicate a strong and positive relationship between distribution justice and OCB in a study conducted by Gilaninia \& Abdesonboli (2011); Chegini (2009); while Arjmand \& Asgari (2011), found no significant relationship between distribution justice and OCB.

\section{The Effect of procedural justice on organizational citizenship behavior (OCB).}

The results of statistical data analysis showed that procedural justice had a positive and insignificant effect on organizational citizenship behavior (OCB). The biggest outer loading value in procedural justice variable is an indicator that makes accurate information to make a decision with a value of 0.881 . This means that the more accurate the information, then it does not affect organizational citizenship behavior (OCB). The results of this study contradict the results of previous studies in which Arjmand \& Asgari (2011), found a significant relationship between procedural justice and OCB, the higher the justice felt by an employee, the higher the OCB level of employees.

Effect of interactional justice on organizational citizenship behavior (OCB)

The results of statistical data analysis show that interactional justice has a positive and insignificant effect on organizational citizenship behavior (OCB). The largest outer loading value in interactional justice variables is an indicator when a decision is made related to work by showing the rights as employees with a value of 0.885 . This means that when a decision is made related to work by showing the rights as employees, it does not affect organizational citizenship behavior (OCB). BPJS employment employees are well aware, that in providing services to participants, it does not depend on whether or not the relationship is built with the boss. The results of this study are in accordance with the results of previous studies in which Jafari \& Bidarian (2012) and Arjmand \& Asgari (2011), in Iranian universities proved that interactional justice did not have a significant relationship with OCB.

The Effect of job satisfaction on organizational citizenship behavior (OCB).

The results of statistical data analysis show that job satisfaction has a positive and significant effect on organizational citizenship behavior (OCB). The biggest outer loading value in the job satisfaction variable is an indicator satisfied with the work with a value of 0.884 . This means that more satisfied with the work, then it affects organizational citizenship behavior (OCB). An employee who is satisfied with his job, generally feels comfortable in the agency, causing a sense of loyalty and willingness to do extra things that are more than just his job. The results of this study are in accordance with the results of previous studies in which Organ \& Ryan (1995), in 28 studies found a correlation between job satisfaction and OCB.

\section{Conclusion}

The results of data analysis statistically show that fair distribution has a positive and significant effect on job satisfaction. Based on the description of the respondent's answer to the equity distribution variable, the "overall reciprocity I receive here is fair" indicator and "I am entitled to my job responsibility is fair", showing the lowest value. Thus, it is recommended for the management of the company to pay more attention to the overall reciprocity that employees get and the justice of the work responsibilities of employees to be able to maximize the level of distribution justice for employees so as to maximize the level of employee job satisfaction.

The results of statistical data analysis show that job satisfaction has a positive and significant effect on organizational citizenship behavior (OCB). Based on the description of the respondent's answer to the equity distribution variable, the indicator "I am satisfied with the award I got for what I have done", shows the results with the lowest value. Thus, it is recommended for the management of the company to be able to provide some form of appreciation for the achievement of work performed by employees to be able to maximize the level of job sat isfaction so as to maximize the level of organizational citizenship behavior (OCB) employees.

Conflict of interest statement and funding sources

The authors declared that they have no competing interest. The study was financed by personal funding.

Indahyati, N., \& Sintaasih, D. K. (2019). The relationship between organizational justice with job satisfaction and organizational citizenship behavior. International Research Journal of Management, IT and Social Sciences, 6(2), 63-71. https://doi.org/10.21744/irjmis.v6n2.611 
Statement of authorship

The authors have a responsibility for the conception and design of the study. The authors have approved the final article.

\section{Acknowledgments}

Future research is expected to be carried out in a wider population, different types of business industries, and different regions, thus the findings may be different as well. The data of this study were taken in one particular time (crosssection), it is suggested that in the future further research can use time series data or research with longitudinal data to produce better research. Subsequent research can add constructs other than distribution justice, procedural justice, interactional justice, and job satisfaction to be able to identify more deeply about organizational citizenship behavior (OCB). 


\section{References}

Altahayneh, Z. L., Khasawneh, A., \& Abedalhafiz, A. (2014). Relationship between organizational justice and job satisfaction as perceived by Jordanian physical education teachers. Asian Social Science, 10(4), 131.

Altinkurt, Y., \& Yilmaz, K. (2012). Relationship between School Administrators' Organizational Power Sources and Teachers' Organizational Citizenship Behaviors. Educational Sciences: Theory and Practice, 12(3), $1843-1852$.

Altinkurt, Y., \& Yilmaz, K. (2012). Relationship between School Administrators' Organizational Power Sources and Teachers' Organizational Citizenship Behaviors. Educational Sciences: Theory and Practice, 12(3), $1843-1852$.

Al-Zu'bi, H. A. (2010). A study of relationship between organizational justice and job satisfaction. International Journal of Business and Management, 5(12), 102.

Arjman, F., Nojabae.S.S., Asgari.H.M. (2011). The Relationship Between the Organizational Justice and Organizational Citizenship Behavior of the Employees. Middle-East Journal of Scientific Research, Vol. 10, No.2, pp. 141-148.

Aslam, R. (2012). Investigating the relationship of ocb with job satisfaction organizational commitment and turnover intensions. Management journal, 1(9), 90-100.

Bakhshi, A., Kumar, K., \& Rani, E. (2009). Organizational justice perceptions as predictor of job satisfaction and organization commitment. International journal of Business and Management, 4(9), 145-154.

Campbell, L., \& Finch, E. (2004). Customer satisfaction and organisational justice. Facilities, 22(7/8), 178-189. https://doi.org/10.1108/02632770410547543

Chegini, G.M. (2009). The Relationship between Organizational Justice and Organizational Citizenship Behavior. American Journal of Economics and Business Administration. 1(2), pp. 173-176.

Colquitt, J. A., Conlon, D. E., Wesson, M. J., Porter, C. O., \& Ng, K. Y. (2001). Justice at the millennium: a metaanalytic review of 25 years of organizational justice research. Journal of applied psychology, 86(3), 425.

Erkutlu, H. (2011). The moderating role of organizational culture in the relationship between organizational justice and organizational citizenship behaviors. Leadership \& Organization Development Journal, 32(6), 532-554. https://doi.org/10.1108/01437731111161058

Fatt, C. K., Khin, E. W. S., \& Heng, T. N. (2010). The impact of organizational justice on employee's job satisfaction: The Malaysian companies perspectives. American Journal of Economics and Business Administration, $2(1), 56$.

Foote, D. A., \& Li-Ping Tang, T. (2008). Job satisfaction and organizational citizenship behavior (OCB) does team commitment make a difference in self-directed teams?. Management Decision, 46(6), 933-947. https://doi.org/10.1108/00251740810882680

George, J. M., \& Bettenhausen, K. (1990). Understanding prosocial behavior, sales performance, and turnover: A group-level analysis in a service context. Journal of applied psychology, 75(6), 698.

Goudarzvandchegini, M., Gilaninia, S., \& Abdesonboli, R. (2011). Organizational justice and organizational citizenship behavior case study: Rasht public hospitals. International Journal of Business Administration, $2(4), 42$.

Halim, W.F., Amiraa, M.A., Fatimah, O. (2011). The Relationships between Organizational Justice, Organizational Citizenship Behavior and Job Satisfaction. Pertanika J. Soc. Sci. \& Hum. 19(5), pp. 115 - 121.

Ince, M., \& Gül, H. (2011). The effect of employees' perceptions of organizational justice on organizational citizenship behavior: An application in Turkish public institutions. International Journal of Business and Management, 6(6), 134.

Jafari, P., \& Bidarian, S. (2012). The relationship between organizational justice and organizational citizenship behavior. Procedia-Social and Behavioral Sciences, 47, 1815-1820. https://doi.org/10.1016/j.sbspro.2012.06.905

Karambayya, R. (1990). Contexts for organizational citizenship behavior: Do high performing and satisfying units have better'citizens'. Unpublished Paper, York University, Ontario.

Locke, E. A. (1976). The nature and causes of job satisfaction. Handbook of industrial and organizational psychology.

Lotfi, M. H., \& Pour, M. S. (2013). The relationship between organizational justice and job satisfaction among the employees of Tehran Payame Noor University. Procedia-Social and Behavioral Sciences, 93, 2073-2079. https://doi.org/10.1016/j.sbspro.2013.10.168

Luthans, F. (2005). Perilaku organisasi edisi sepuluh, diterjemahkan oleh: Vivin Andhika Yuwono. Shekar Purwanti. Th Arie Prabawati, dan Winong Rosari Penerbit Andi Yogyakarta.

Mehboob, F., \& Bhutto, N. A. (2012). Job satisfaction as a predictor of organizational citizenship behavior a study of faculty members at business institutes. Interdisciplinary journal of contemporary research in business, 3(9), 14471455.

Mohammad, J., Quoquab Habib, F., \& Alias, M. A. (2011). Job Satisfaction and Organisational Citizenship Behaviour: an Empirical Study at Higher Learning Institutions. Asian Academy of Management Journal, 16(2).

Indahyati, N., \& Sintaasih, D. K. (2019). The relationship between organizational justice with job satisfaction and organizational citizenship behavior. International Research Journal of Management, IT and Social Sciences, 6(2), 
Podsakoff, P. M., \& MacKenzie, S. B. (1997). Impact of organizational citizenship behavior on organizational performance: A review and suggestion for future research. Human performance, 10(2), 133-151. https://doi.org/10.1207/s15327043hup1002_5

Posdakoff, P. M., \& MacKenzie, S. B. (1994). Organizational citizenship behaviors and sales unit effectiveness. Journal of marketing research, 31(3), 351-363. https://doi.org/10.1177\%2F002224379403100303

Rastgar, A. A. (2013). A study of the relationship between organizational justice and turnover intentions: Evidence from Iran. International journal of research in organizational behaviour and human resource management, 1(2), 1.

Sareshkeh, S. K., Ghaziani, F. G., \& Tayebi, S. M. (2012). Impact of organizational justice perceptions on job satisfaction and organizational commitment: The Iranian sport federations perspective. Annals of Biological Research, 3(8), 4229-4238.

Shokrkon, H., \& Naami, A. (2008). The relationship of job satisfaction with organizational citizenship behavior and job performance in Ahvaz factory workers.

Siregar, S. (2013). Statistik parametrik untuk penelitian kuantitatif. Jakarta: Bumi Aksara, 102.

Sugiyono. (2012). Metode Penelitian Kuantitatif Kualitatif dan R\&D. Bandung: Alfabeta

Swaminathan, S., \& Jawahar, P. D. (2013). Job satisfaction as a predictor of organizational citizenship behavior: An empirical study. Global Journal of Business Research, 7(1), 71-80.

Van Dam, K., Oreg, S., \& Schyns, B. (2008). Daily work contexts and resistance to organisational change: The role of leader-member exchange, development climate, and change process characteristics. Applied psychology, 57(2), 313-334. https://doi.org/10.1111/j.1464-0597.2007.00311.x

Venkatesh, J., Vivekanandan, K., \& Balaji, D. (2012). Relationship among emotions, mood, personality and clothing: an exploratory study. Elixir Psychology, 45, 7923-7926.

Wiili-Peltola, E., Kivimäki, M., Elovainio, M., \& Virtanen, M. (2007). Organisational justice and employee perceptions on hospital management. Journal of Health Organization and Management, 21(3), 320-332. https://doi.org/10.1108/14777260710751771 


\section{Biography of Author}

\begin{tabular}{ll|l|} 
Nurul Indahyati finished her Master Degree at Udayana University. She interested in \\
Management field especially human resources management. \\
Email: nurul.indahyati@bpjsketenagakerjaan.go.id
\end{tabular}

Indahyati, N., \& Sintaasih, D. K. (2019). The relationship between organizational justice with job satisfaction and organizational citizenship behavior. International Research Journal of Management, IT and Social Sciences, 6(2), 63-71. https://doi.org/10.21744/irjmis.v6n2.611 